\title{
Literacy Culture Development through Class Library at SDIT Salsabila 2 Klaseman Ngaglik Sleman
}

\author{
Ahmad Safi' i \\ STPI Bina Insan Mulia Yogyakarta \\ ahmad210285@gmail.com
}

\begin{abstract}
Life skills are proven to be able to improve human civilization. Improving literacy culture is one way to develop human life skills. The National Literacy Movement/ Gerakan Literasi Nasional (GLN) initiated by the government is an effort to realize it. SDIT Salsabila 2 Klaseman has a Class Literacy Movement/ Gerakan Literasi Kelas (GLK) program. The limited space available is not a reason to discourage GLK. This type of research was case study field research. The institution studied was SDIT Salsabila 2 Klaseman. The subjects consisted teachers, principals, students and parents. Data was obtained by observation, interviews and documentation steps. Analysis was performed by using data reduction techniques, data display, triangulation, and conclusion drawing/verification. The data showed that the main purpose of GLK was to intensify the culture of school literacy, library revitalization, and maintain the stability of school library functions. The technical implementation is by creating a class library in each class, fostering a sense of belonging to the class library, supplying books from the school library to the class library, providing educational playgrounds in the area of the class library, giving rewards for students who are diligent in reading, achievements are informed in public, and explore the student guardian support. The problems that arise are the lack of teacher exemplariness, lack of consistency, supply of books from school libraries is still small, and the system of re-education has not been orderly.
\end{abstract}

Keywords: development, literacy culture, class library 


\section{INTRODUCTION}

Abundant Natural Resources (SDA) owned by a nation does not necessarily guarantee the nation's progress. The potential of abundant SDA if it is not accompanied by quality of Human Resources (SDM) will only have stagnated and even waited the destruction. The presence of qualified human resources becomes very important as a manager of nature conservation. History proves that the abundance of natural resources owned by the Indonesian people has become an easy target for the colonizers. Awareness of the importance of managing land itself and the expulsion of invaders built by educated or heroes to the population made Indonesia achieve independence. Human resources that have skills are proven to be able to change the history of civilization of a nation.

Life skills can be built by enhancing literacy culture. In the era of the industrial revolution 4.0, searching information with many themes in science from various reading sources can be done easily. Through a smartphone in the palm of your hand, everyone can search for whatever information you want. Thus, increasing reading interest should be made as the main concern towards the literacy door.

The Indonesian nation, according to The Pew Forum on Religion \& Public Life, in 2010 Indonesia was the largest Muslim country in the world with 205 million Muslims (https://m.republika.co.id/amp/noywh5 ). The holy message of Muslims is the Qur'an, along with that the revelation that was first revealed by Allah SWT to the Prophet Muhammad is the Surah QS. Al-'Alaq, the main essence is the command to read (iqra'). 


\section{Mudarrisa: Jurnal Kajian Pendidikan Islam, Vol. 11, No. 2, 2019}

Thus, as a great nation which also has the largest Muslim population in the world, ideally respect the command of iqra' through practicing it in our daily lives. Ironically, according to the study of Most Littered Nation in the World 2016, interest in reading in Indonesia ranks 60 out of 61 countries.

\section{(http://www.tribunnews.com/regional/2017/05/15/memprihatinkan-ternyata-} minat-baca-indonesia-duduki-peringkat-60-dari-61-negara).

The presence of the National Literacy Movement (GLN) is one of the ways in which the government implements a culture of literacy in the community. Integrated education patterns between schools, parents and the community become an inseparable part in creating a capable society. Building a high reading interest, supported by the availability of quality and affordable reading material, will encourage reading and writing habituation, both in schools and in the community (Kemendikbud, 2017: $5)$.

One of the implementation of GLN is the School Literacy Movement. School Literacy Movement (GLS) is a literacy movement whose activities are mostly carried out in schools involving students, education and education personnel, as well as parents. GLS is done by displaying good practices about literacy and making it a habit and culture in the school environment. Literacy can also be integrated in teaching and learning activities in schools so that it becomes an inseparable part of all the series of students' activities and educators, both inside and outside the classroom (Kemendikbud, 2017: 19). 


\section{Mudarrisa: Jurnal Kajian Pendidikan Islam, Vol. 11, No. 2, 2019}

SDIT Salsabila 2 Klaseman Ngaglik Sleman is one of the elementary schools based on Islamic values that have an interest in the literacy program. As the school which develops with so many applicants every year, the school is expanded into two locations or two units, where the distance between them of about 350 meters. Unit I accommodates 3 classes while Unit II has 14 classes. Interestingly, the location of library is in unit 1 with only 3 classes, not in unit 2 with the more classes, including the number of learners, and at glance it needs more library functions. The main reason is the limited available space. Finally, the school took clever steps by making the movement of literacy classes, where each class makes their library. (Interview with Zaelani, principals, August 6, 2019).

A similar study was carried out by Yati Kurniawati at SMP 10 Salatiga with the title "Efforts to Achieve Literacy Schools through Gelis Batuk". Gelis Batuk is an abbreviation for Literacy Movement of Reading, Writing and Works. Gelis Batuk becomes the basic point in the study discussion. (Kurniawati, Teacher and Educational Staff Symposium, Salatiga, 2016). Saliyo wrote in her research that one of the quality supporting facilities for studying in higher education is the existence of a library. (Saliyo. 2016. the Role of Library in Improving Students' Quality with Different Cultural Background. Libraria. Vol. 4 No. 1. p.1). The difference with this research is the level of the education unit which automatically impacts on the subjects of the study, the strategy of implementation in the field and the problems in it.

The Class Literacy Movement that was implemented at SDIT 
Salsabila 2 Klaseman is interesting to peel deeper, starting from the concept, its implementation, problems and the efforts made to overcome them. This will be an inspiration in the midst of limitations for other schools that have the same fate.

\section{METHODS}

This type of research is field research in the form of case study. Qualitative research involves written and oral data of the observed informants. The location of this research is SDIT Salsabila 2 Klaseman Sinduharjo Ngaglik Sleman. Data was collected from August 6, 2019 to August 10, 2019. The research subjects were the principal, teachers, students and parents. Data obtained through observation, interviews and documentation. Analysis was performed using data reduction techniques, data display, triangulation and conclusion drawing/verification.

\section{DISCUSSION}

The Concept of Class Literacy Movement (GLK) at SDIT Salsabila 2 Klaseman

The data of this study were obtained from interviews with school principals and SDIT Salsabila 2 Klaseman teachers. The results of the interviews obtained are then narrated in the paragraphs below.

Class Literacy Movement (GLK) carried out by SDIT Salsabila 2 Klaseman is a response to the awareness towards the importance of literacy culture. In the middle process of developing a learning building that quite influences the stability of learning and library functions, the school encourages teachers and students to always revive literacy culture through 


\section{Mudarrisa: Jurnal Kajian Pendidikan Islam, Vol. 11, No. 2, 2019}

GLK. Zaelani, the principal said that the main purpose of GLK is to intensify the culture of school literacy, library revitalization, and maintain the stability of school library functions. The culture of school literacy or the School Literacy Movement (GLS) is a derivation of the National Literacy Movement initiated by the government, so SDIT Salsabila 2 Klaseman took part in the mandate. Revitalization and stabilization of the library is intended as an effort to improve the function of the library again so that it is not affected by the ongoing classroom development. (Interview, August 6, 2019).

Initially, all reading resources were centered in the school library, in its development it was distributed to all classes through GLK without compromising the function of the school library. The main reason is the capacity of the library for interested readers. Occasionally a large number of reading enthusiasts from various classes visit at the same time even though a visit list has been made. Through GLK the problem can be dealt with and the circulation of lending in the school library is also more stable. GLK provides a broad space for each class to enrich the source of literacy is not limited to only books available in the school library. The naming of GLK in each class also varies depending on class tastes, some are Reading Corner, Literacy Corner, Literacy Station, Literacy Tree, Class Library, and so on (Interview with Zaelani, 6 August 2019).

The school library is one of the sources of reference for the development of science and technology which exist there. Teachers and students can create literacy culture through optimization of library 
functions. Junaeti asserted that the availability of libraries with adequate collections and services is one of the main and essential facilities (Antonio, Soares, \& Parreiras, 2018; Arwan \& Agus. 2016: 16).

\section{Development of Literacy Culture}

Humans have a literal soul that is already inside them. The ability to communicate with a variety of languages, the ability to create culture, and the ability to survive is a basic ability possessed by humans (Heitmann et al., 2017: 3). The desire to seek and understand knowledge, explore various sources of information, find experiences that can be utilized to identify the characteristics of other human conditions, the universe and animals. Indeed, the illustration is the power of literacy. (Efendi \& David, 2019: 24).

Since 2016, Ministry of Education and Culture (Kemendikbud) intensified the National Literacy Movement (GLN) as part of the implementation of the Regulation of Minister of Education and Culture No. 23 of 2015 about Character Growth. The Ministry of Education and Culture forms the GLN working group to coordinate various activities managed by related work units. In the 2013 curriculum the form of reading literacy development requires students to read 15 minutes before the lesson begins, not textbooks but the books enrichment, both enriching the knowledge, skills, and personality. In the 2004 Curriculum and KTSP were actually revealed about the need to read a number of books, but because they were not tagged as learning outcomes the results were not significant. Therefore, learning of literacy reading is done and put into 
Basic Competency which must be billed by teachers as a result of learning in 2013 curriculum. Otherwise, SD/MI Students thoroughly studied Indonesian subject if they have read a minimum number of 6 titles enrichment of knowledge, skills, and personality. This means that since students are in grade 4 must be able to read at least 2 titles, so that up to class VI they will be able to read 6 titles. (Suherli, 2017: 3).

The Concept of Class Literacy Movement (GLK) at SDIT Salsabila 2 Klaseman

School library is a place, building, space provided for the maintenance and use of book collections and access information that supports the literacy activities of its members (Mahwasane, 2017; Sobirin \& Susapti, Salatiga, 2018: 210). In addition, the library is a dynamic space as a center for the development of human works that cannot be separated from the state of library progress that is available because the library is the heart. (Saliyo. 2 016: 2).

The implementation of GLK in SDIT Salsabila 2 Klaseman has standard steps that must be followed by the implementers; however the implementers are still allowed to improvise according to the needs of the class as long as they do not go out of the goals that have been formulated. Therefore, SDIT Salsabila 2 Klaseman compiled and made certain steps in implementing the improvement of literacy quality in the environment.

Every year, SDIT 2 Klaseman always holds a class decoration and cleanliness contest, one of the main elements assessed is the existence of a class library. This competition requires harmonious cooperation between 
class teachers, students and guardians of students to encourage each class to enliven their class library. In addition to the books available in the class library, information about science and technology are also presented by the class teacher through the class wall and the science corner. An important element that cannot be ignored in class library is the design of the library in order to attract visitors; each teacher must design a class library to make it looks attractive. It also became one of the elements of evaluation in the class decoration and cleanliness competition. The library design of SDIT Salsabila 2 Klaseman is illustrated in Figure 1.

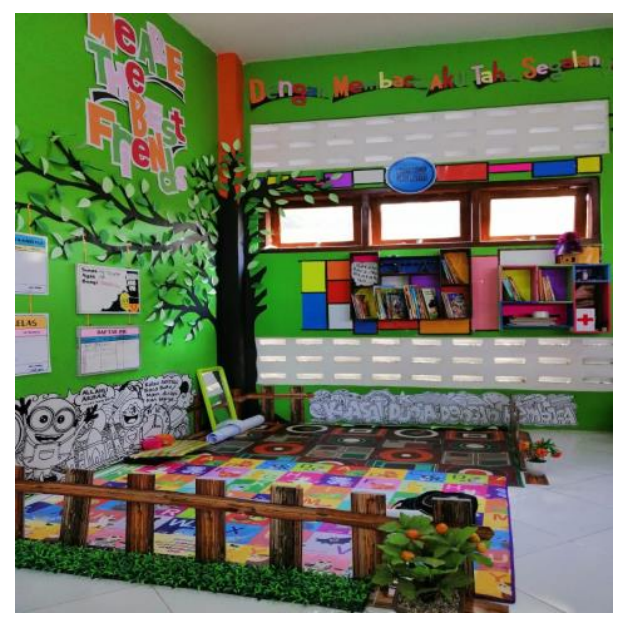

Figure 1. Literature of Class 4 Ahmad Dahlan SDIT Salsabila 2 Klaseman

Aside from being support, cooperation that involves teachers, students and the parents build a sense of belonging to the class (McGrath $\&$ Van Bergen, 2015: 15). One concrete example is a book grant made by students and the parents. The book grant is intended to share benefits with fellow friends. Books that have been piled up at home can be brought to class to become a collection that can be widely read by other 
students.

The supply of books from school libraries to class libraries can be done as a strategy to suffice the limited number of books available in class libraries. Books in class libraries have often been read by children so the class teacher submitted a list of books' rows to be borrowed to be put in the relevant class. Book lending can be done at any time for one week with the borrower's data collection.

Not only books, educational game tools ware also provided in the library as a place for students to be part of learning (Pratiwi, 2017: 3; Sari, 2018: 73; Sudiana et al., 2017: 7). Nana Syaodih Sukmadinata (2009: 123) asserted that during elementary school, one of the great motivations experienced by children was the encouragement to perform various forms of games and activities that demanded physical skills/ movements. Physical games in the library are designed so that physical activity is not too high, but it can stimulate children to be creative and strategic as in Figure 2. The availability of playing equipment is intended to attract the attention and interest of children so that they come to the class library.

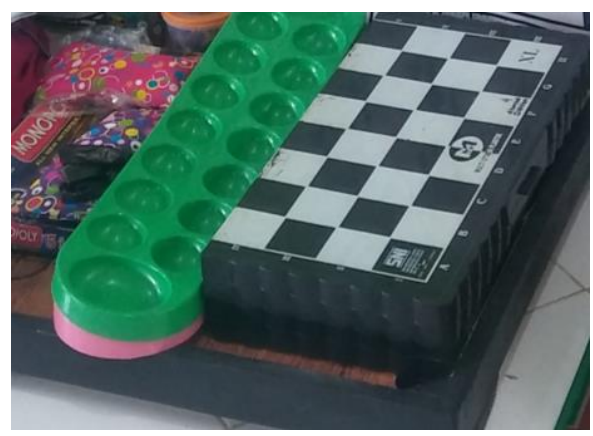

Figure 2. Examples of playing instruments in Class 5 Umar bin Khattab 


\section{Mudarrisa: Jurnal Kajian Pendidikan Islam, Vol. 11, No. 2, 2019}

Diligent playing is certainly not rewarded even though what is played is an educational game that is available in the class library. It was different if the child is diligent in reading, then various rewards from the classroom teacher through class Infāq subsidies will be received by the child. Children had the choice of coming to class library to play but cannot get a gift or come to read and have a chance to get a gift. Behaviorism Flow asserts that learning is a process of changing behaviour in responding to environment stimuli (stimulus). Behavior is formed through positive or negative behavior immediately, after the learner performs a certain behavior (Pinto \& Laure. 2014: 3; Staddon, 2017: 230). Children who have achieved the predicate of diligent reading were announced to the school community at the ceremony or morning apple on Monday. The purpose of this was to form a sense of pride and enthusiasm in children to continue to diligently read. Slameto (2003: 98-99) asserts that a teacher should always try to foster, maintain, and increase student motivation. Announcing children's achievements in public was believed by teachers to increase children's confidence and encourage them to become better.

Education in the family environment with the school environment must work together. That was not clear at school must be known at home to be given further assistance. If there was a gap in information regarding children's behavior, they must look for relationship with information from home. Schools and homes had to be trust each other (Shaleh, Abd. 2005: 271-272). Students' parents support was very important in supporting 
school activities. Murray wrote about the role of a number of schools that formed a "Parent Advisory Committee" (PAC) or an association to organize communication between parents and schools, including: a) providing facilities for principals and teachers, b) publishing information to parents, c) conduct pilot projects, d) determine and create a social function (Majid, Abdul. 2011. p. 160). No exception at SDIT Salsabila 2 Klaseman, the role of the class committee is very important especially in meeting all class needs.

The success of an organization is influenced by the performance (job performance) of human resources (HR), for that every organization will strive to improve the performance of $\mathrm{HR}$ in order to achieve organizational goals. Along with that, an organization needs a system standard that can be understood by all HR so that all implementers are in the right corridor in carrying out their duties (Kusumastuti \& Suryaningrum. 2014: 4).

Problems of Class Literacy Movement (GLK) at SDIT Salsabila 2 Klaseman

Gagne states that problems arise if the goals that have been formulated have not yet been achieved. Meanwhile, Newell \& Simon explain that a problem is a situation where someone wants something but does not know how to achieve it (Siti, 2018: 6). As one of the programs implemented at SDIT Salsabila 2 Klaseman, GLK encountered several challenges in their program.

Building a culture of literacy for children requires exemplary 


\section{Mudarrisa: Jurnal Kajian Pendidikan Islam, Vol. 11, No. 2, 2019}

behavior especially from figures respected by children in surrounding environment, for example parents and teachers (Wulandari \& Kristiawan, 2017: 297). Problem experienced by students at SDIT Salsabila 2 Klaseman was the lack of encouragement for parents' model at home. Teachers should be able to become literacy agents in schools, by reactivating school wall magazines. A good attitude also required consistency in its implementation in order to form good habits.

It needed consistence attitude of the doer of education to achieve the goal. Developing a culture of literacy in schools was part of the educational process that needs consistency in the implementation. Consistency that had to be improved is exemplary diligent reading, availability of books, giving appreciation, and announcements in public. Factors that influence in decreasing consistency was the monitor power is still less from the principal.

The total collection of books in the library SDIT Salasabila 2 Klaseman had amount of 1500 books. Whereas, the school had a number of 17 classes, so the safe availability was amount of 5 books per class per week. This considers the number of students on average was amount of 25 students, then the total availability of the book was considered minimal because the number of readers' interest was substantially greater than the amount of available.

The problem started was the borrow-back system in GLK arranged according to the needs of each class. Some classes write on the classroom wall, others wrote some column in special notebooks. Problems occured 
when students who borrowed the books, then they forgot to write their personal data and books that are borrowed. So that, the books which made the regulation of borrowing books were not organized well. In addition, schools had not specifically regulated book lending standards in GLK so that supervision from schools was less intensive.

Teaching programs in good schools are teaching that is able to provide great support to students in completing their development tasks (Baharuddin, 2009: 164). Along with that, GLK should be integrated with teaching programs in schools to support the achievement of objectives. School support is able to provide students with the availability of GKL (Pétervári et al., 2016: 12; Rambousek et al., 2016: 375).

\section{Efforts of SDIT Salsabila 2 Klaseman in Handling Class Literacy Movement (GLK) Problems}

Following up problems that arise in a program needs to begin with an evaluation process. According to Dedi Lazwardi in Sudjana (2006: 21) is an effort to gather information about a program, activity or project. The information is useful for making decisions, to improve the program, perfecting further program activities, stopping an activity or disseminating ideas that underlie a program or activity ( Dedi. 2017 : 144).

Humans are creatures that develop because they are influenced by nature and the environment is one of the essences of human form (Ahmad et al., 2012: 51). Teachers are expected to be able to create a literal environment in their class (Hitipeuw \& Malang, 2018: 808). The teacher's sample was the right way to realize it because in general the teacher is more 


\section{Mudarrisa: Jurnal Kajian Pendidikan Islam, Vol. 11, No. 2, 2019}

obeyed by students than the students' guardians or parents (parents interviewing result, Suharto, August 25 2019).

Being an example in the field of literacy was not easy in this case. SDIT Salsabila 2 Klaseman had attention on this topic. Therefore, the school gave special appreciation to teachers who are able to set an example for their students in the field of literacy (Interview with Zaelani, 6 August 2019).

Habituation is considered to be very effective if the application is carried out on young students, because it has a strong memory record and an immature personality condition. Not only children, habituation also needed to be activated by adults (teacher/parents) as a companion to child development. Habituation needed to do by the teacher to provide exemplary by reading diligently, consistent in supplying book, consistent in appreciating students who read diligently, and make routine announcement of learners' achievements in public.

Adding the number of book collections starts from the school library. This is intended as a preparation for the supply of books in classes or class libraries. Although it has not yet been implemented, this program has been planned as a development step carried out by SDIT Salsabila 2 Klaseman.

SDIT Salsabila 2 Klaseman has not yet provided lending standards to GLK. Existing standards existed only in the school library, not in the class library. Actually, it is intended to provide flexibility for class teachers to be creative in the GLK system. One side, it provides facilities for 
creative classroom teachers but on the other hand it is difficult for pattern evaluation. Therefore, a standardized system will be tried to facilitate the evaluation system.

SDIT Salsabila 2 Klaseman needs to standardize the literacy program which is applied there, from planning, implementation, evaluation to accountability and development. So far, the implementation of GLK has not been neatly documented so that the implementation has not been detected in previous years. This is important to be used as a guide for the implementation or development of similar programs in the following year.

\section{CONCLUSION}

GLK is a derivative of GLN program initiated by the government. The GLK program implemented by SDIT Salsabila 2 Klaseman has three main objectives, namely to intensify the culture of school literacy, to revitalize libraries, and to maintain the stability of school library functions. The technical implementation of GLK in the school consists of several steps, including: creating a class library, fostering a sense of belonging to the class library, supplying books from the school library to the class library, providing educational play tools in the area of the class library, giving rewards for students who read diligently, achievements are informed in public, and explore the support of students' parents.

In the implementation, there were a number of things that need improvement, namely lack of exemplary, lack of consistency, supply of books from the school library was small, and the system of borrow-back has 
not been regulated. SDIT Salsabila 2 Klaseman need to develop a system to improve the GLK, for example, expanding the number of books in the school library routinely and periodically, open digital library, giving appreciation to teachers who are able to be exemplary literacy for learners, improve the consistency of teachers in taking notes and announcing the students' reading achievements, increase the number of books supplied to the class, and create a standard borrow-back system on the GLK clearly for all classes.

As a school program, GLK must be documented from the process of the beginning to the end in order to become the next development material. In addition, each subject teacher is encouraged to be able to integrate his teaching material with GLK so that the learning objectives and GLK remain in harmony.

\section{REFERENCES}

Antonio, M., Soares, C., \& Parreiras, F. S. (2018). A literature review on question answering techniques, paradigms and systems. Journal of King Saud University - Computer and Information Sciences, 806-809.

Arikunto, S. (2010). Prosedur Penelitian Suatu Pendekatan Praktik. Jakarta: PT Rineka Cipta.

Danim, Sudarwan. (2002). Menjadi Peneliti Kualitatif, Bandung: CV. Pustaka Setia.

Daryanto. Raharjo, Muljo. (2012). Model Pembelajaran Inovatif, Yogyakarta: Gava Media. 
Dewayani, Sofie. (2017). Menghidupkan Literasi Di Ruang Kelas, Yogyakarta: PT Kanisius.

Efendi \& David. 2019. Gerakan Literasi di Indonesia: Progresif atau Regresif? Pundi: Majalah Pegiat Pendidikan Indonesia, 2, 1, 22-28.

Endah, Alberthiene. (2012). Prof. Dr. Suharyadi Mendidik dengan Hati, Jakarta: PT. Gramedia Pustaka Utama.

E. Pinto, Laure. Spares, Stephanie. Driscoll, Laura. (2014). 95 Strategi Pengajaran, Jakarta: PT. Indeks.

Heitmann, P., Hecht, M., Scherer, R., \& Schwanewedel, J. (2017). Learning Science Is About Facts and Language Learning Is About Being Discursive- An Empirical Investigation of Students' Disciplinary Beliefs in the Context of Argumentation. Frontiers in Psychology, 8(June), $1-24$.

Hitipeuw, I., \& Malang, P. N. (2018). Hubungan Motivasi Belajar dan Tindakan Guru dengan Prestasi Belajar Siswa dengan Latar Belakang Broken Home Kelas V Sekolah Dasar. Jurnal Pendidikan: Teori, Penelitian, Dan Pengembangan, 3(6), 806-809.

Junaeti. Arwan, Agus. 2016. Peranan Perpustakaan dalam Meningkatkan Kualitas Perguruan Tinggi (Konstruksi Pelayanan, Strategi, dan Citra Perpustakaan). Libraria, 4, 1, 22-30.

Kalida, M. (2012). Fundraising Taman Bacaan Masyarakat (TBM). Yogyakarta: Aswaja dan Cakruk Publising. 


\section{Mudarrisa: Jurnal Kajian Pendidikan Islam, Vol. 11, No. 2, 2019}

Kusmana, Suherli. 2017. Pengembangan Literasi Dalam Kurikulum Pendidikan Dasar dan Menengah. Diglosia: Jurnal Pendidikan, Kebahasaan, dan Kesusastraan Indonesia, 1, 1, 145-148.

Lazwardi, Dedi. 2017. Implemetasi Evaluasi Program Pendidikan di Tingkat Sekolah dasar dan menengah. Al-Idarah: Jurnal kependidikan Islam, 7, 140-116.

Majid, Abdul. Andayani, Dian. (2011). Pendidikan Karakter Perspektif Islam, Bandung: Remaja Rosdakarya.

Mahwasane, N. P. (2017). The Influence of School Library Resources on Students' Learning: A Concept Paper. International Journal of Educational Sciences, 17. https://doi.org/10.1080/09751122.2017.1305739

McGrath, K. F., \& Van Bergen, P. (2015). Who, when, why and to what end?

Students at risk of negative student-teacher relationships and their outcomes.

Educational Research Review (Vol. 14). Elsevier Ltd.

Pétervári, J., Osman, M., \& Bhattacharya, J. (2016). The role of intuition in the generation and evaluation stages of creativity. Frontiers in Psychology, 7 (SEP), 1-12. https://doi.org/10.3389/fpsyg.2016.01420

Pratiwi, W. (2017). Konsep bermain pada anak usia dini. TADBIR: Jurnal Manajemen Pendidikan Islam, 5(2).

Purwanto, Ngalim. (2011). Psikologi Pendidikan, Bandung: Remaja Rosydakarya.

Rambousek, V., Štípek, J., \& Vaňková, P. (2016). Contents of Digital Literacy from the Perspective of Teachers and Pupils. Procedia - Social 
and Behavioral Sciences, 217, 354-362.

Saliyo. 2016. Peran Perpustakaan dalam Meningkatkan Kualitas Mahasiswa

Dengan Berbagai Latar Belakang Budaya. Libraria, 4(1), 1-14.

Sami', Abdus. Moin, Abdul. (2010). The Holy Qur'an: With Colour Coded Tajweed Rules in Indonesian Language, Jakarta: Lautan Lestari.

Sari, D. Y. (2018). Peran Guru dalam Menumbuhkan Literasi melalui Bermain pada Anak Usia Dini. Golden Age: Jurnal Pendidikan Anak Usia Dini, 1(Desember 2017), 69-76.

Sugiyono. (2005). Memahami Penelitian Kualitatif, Bandung: CV. Alfabeta.

Sugiyono. (2010). Metode Penelitian Pendidikan: Pendekatan Kuantitatif, Kualitatif, dan R EF B. Bandung: Alfabeta.

Sudjana, Djudju. 2006. Evalusi Program Pendidika Luar Sekolah. Bandung: Remaja Rosdakarya.

Slameto, (2003). Belajar dan Faktor-Faktor yang Mempengaruhinya. Jakarta: Rineka Cipta.

Syaodih Sukmadinata, Nana. (2009). Landasan Psikologi Proses Pendidikan, Bandung: Remaja Rosdakarya.

Sobirin, M., Susapti, P., \& Salatiga, I. (2018). Cultural literacy building of primary school students as basic concept. Mudarrisa: Jurnal Kajian Pendidikan Islam, $\quad$ 10(2), 206-221. https://doi.org/10.18326/mudarrisa.v10i2.206-221

Staddon, J. (2017). Theoretical Behaviorism. In In Behavior and Philosophy, $217-241$.

Sudiana, I. N., Lestari, L., F, M. Z., Ariyani, Y., Sandra, G. E., Biringgalo, 
Mudarrisa: Jurnal Kajian Pendidikan Islam, Vol. 11, No. 2, 2019

Y., ... Safitri, E. (2017). Pembuatan Briket Energi Tinggi dari Cangkang Kakao yang diaktivasi dengan Mokrowave. Jurnal Aplikasi Fisika, 13(1), 27-32.

Tafsir, Ahmad. (2012). Ilmu Pendidikan Islam. Bandung: PT. Remaja Rosdakarya.

Tarigan, H. G. (2008). Membaca sebagai Suatu Keterampilan Berbahasa. Bandung: Angkasa

Yeni Wulandari, M. K. (2017). Strategi Sekolah dalam Penguatan Pendidikan Karakter bagi Siswa dengan Memaksimalkan Peran Orang Tua. Jurnal Manajemen, Kepemimpinan, dan Supervisi Pendidikan, 2(2), $290-303$.

Yunus, Mahmud. (2014). Tafsir Qur'an Karim, Jakarta: Hidakarya Agung. 